-HIGHER-

EDUCATION

-POLICY-

Editorial

\title{
Higher Education and Aspects of Transition
}

Higher Education Policy (2006) 19, 1-5. doi:10.1057/palgrave.hep.8300115

In a world where the view is widely held that change is both a necessary, desirable and an unavoidable state, one of the first casualties is the notion of transition. For, if change becomes permanent - an interesting compliment unwittingly paid by higher education gurus of all shapes, sizes and expertise to the shades of the late Mao Tse Toung, who held much the same ideas about party and polity - the notion of transition itself disappears. Or, to be more precise, its focus is realigned. Transition has less to do with that which is passing, than with that which is to come. This is an important shift in mental perspective. It casts aside the notion of institutional development as 'transition from' but rather puts great emphasis and weight on the notion of 'transition $t o$ '.

The notion of 'transition to' serves to remind us that what is involved in this very particular version of transition is very far from being a situation of permanent and acquired stability. This it would have been, had transition been conceived as once it was - as a celebration to mark having rid ourselves of earlier and, for that reason erroneous practice, inefficient ways of funding, governing or managing either the higher education system or the individual institutions within it.

\section{The Passing of Things or the Anticipation of Others}

Once transition is seen in terms of moving towards a doubtless glorious future - rather than wingeing like the Ancients about the passing of an undoubtedly glorious past (sic transit Gloria Mundi) - we cannot but be reminded by the very nature of transition as an act of anticipation that we live indeed in a condition of emphemerity. Changed we might be. Our present state is conditional, precarious and imperfect, fit only to be maintained as a temporary way station on the ever-upward path towards perfection, which is always brought nearer by the next reform.

The notion of transition anticipated is, not surprisingly, a very old theme. Across the centuries, it has coloured many strange and millennial beliefs. And 
2

while in these exact terms it has not always applied to higher education or, for that matter to higher education policy, transition anticipated has an ancestry so long and so honourable that one may trace it back at the very least to the Ionian philosophers and to the teachings of one of the foremost among them, Heraclitus. As applied to higher education, whether at the system level or at the level of the individual institution, the notion of 'transition to' emerges in the form of the much used language managerial metaphysics - 'conditionality' 'adaptability' and 'flexibility'. Such attributes, like most credos, set order upon a new base. From this standpoint, their present day emphasis would appear to be little more than the insertion into the domains of organizational analysis and the establishment in the firmament of higher education of a new order of Powers Dominations, Thrones, defined managerially rather than celestially.

\section{A Millennial Vision}

It is, however, a view that derives from a very ancient mental set, stripped of course of its theological trappings but endowed with a contemporary doxology that owes much to a fashionable terminology, variously culled from what may be seen as the utilitarian sciences of human behaviour - business, accounting and economics. With transition now set in its anticipatory construction - as looking forward, rather than back over one's shoulder from where one has come - in truth the world of higher education finds itself in a state akin to the Heraclitan world where 'all is in flux'. Hence, 'the state of flux', which is an earlier way of describing conditionality, precarity and impermanence, is often presented in the literature of management as a conditio sine qua non for being ready and able - if not always willing - to take on board the next reform whatever it is - accreditation, cross-border education, the Bologna process or Information Technology.

\section{Detachment}

Indeed, one may even reverse the relationship between reform and transition and see transition less as the process by which earlier reforms worked their way into the fundamental tissue of system and institution. On the contrary, transition becomes detached from the process of previous implementation. It is no longer associated with reform on the way to completion. Once change becomes permanent, there can be no period of settlement and stability. Transition in its anticipatory mode gives rise to a situation in which the 
capacity to continually change and evolve, whether it is called the 'readiness to adapt' or enhancing institutional flexibility, itself becomes one of the objectives of reform. Bolstering up the university's capacity rapidly to take on further reforms, the curtailing of the period of transition becomes as much a desirable condition as reform itself, since it is the prior condition to be able to rapidly assimilate change.

\section{Aspects of Transition}

This issue of Higher Education Policy explores a number of dimensions within the broader process of transition. Without greatly stretching the imagination nor doing injustice to careful scholarship, one may bring into the arena of transition studies that would otherwise be classified as access to or participation in higher education. In effect, what is often known as the 'articulation' between secondary school and university figures as one of the classic forms of the transitional process. Once we set down this perspective, we see for instance that the articles by LeTendre, Geertz Gonzalez and Nomi on the evolution of elite paths from star high schools to Elite universities in the United States and Japan share a certain generic similarity with the contributions from Matear on barriers to access in Chile since 1990 and with the analysis of an undergraduate selection policy in a Saudi Arabian university by Al Dosary and Rahman.

\section{Different Dimensions Addressed}

Agreed, the points of transition examined differ. The first analysis concentrates on changes in institutional policy vis a vis highly selective secondary schools, where as Matear is concerned less with exit from school and entry to higher education so much as the latter part of transition to higher education, the question of who enters. Al-Dorsary and Rahman, however, are concerned with transition from first year undergraduate study and the conditions that govern subject choice in the second year. All three, however, relate to the question of student flows into and partially through higher education.

\section{Accreditation}

Stensaker and Harvey examine different forms of accreditation in Western Europe. At present, new forms of accreditation, the prime feature of which is their location in specialized agencies with varying degrees of 
autonomy and independence from the government and national Ministry of (Higher) Education or its equivalent, are a major issue. These agencies, whether public (which is not greatly exceptional in Europe) or private (which is rather rarer), provide the administrative means of oversight and control of the quality of higher education when political mobilization around the European Higher Education Area and student mobility within it represent grosso modo, another edition of transition. Clearly, their focus dwells on the system level and explores some of the implications that arise and very especially in connection with the possible development of what they term an 'accreditation market' within the European Higher Education Area.

\section{Transition and Academia's Liberties, Freedom and Autonomy}

Leaving aside whether the perspective of change involves transition from or transition to, one of the abiding tensions that so often surfaces is the anticipated consequences transition may have on the abiding values of the university and most particularly so in the area of Academic Freedom. This issue is developed by Justin Thorens, who brings a legal perspective to the historical evolution of this central article of academic faith. He also examines some of the basic linguistic differences and the social as well as political structures that have shaped them. Liberties, Freedom and Autonomy reflect some of the substantial differences in understanding, their sous entendus and cultural associations, which, all too often, are passed over in translation, but which nevertheless are important in dissecting the variations in culture and belief that, both in the past and today, are still powerful tools in defining the reality of the conditions under which the Academic Estate sees as necessary for the advance of its work.

\section{The Global Level}

Finally, Prado Yepes examines a further dimension in transition, that is, the emergence of what he terms 'new macro processes' at the global level. His particular concern however is to make suggestions as to the role that the major international organizations engaged with higher learning and higher education should take. This is a timely contribution. The ambitions of the World Trade Organization to bring learning under its ambit on the grounds that it is a tradable commodity have become more precise. They begin to drive wedges between those countries that see an advantage for themselves in this commerce 
and those who look upon it with no little misgiving. That higher education and educational agencies of an international sweep should take a firmer stance on this agenda is very certainly an idea whose time is come. Whether the timing is recognized remains the heart of the matter.

Guy Neave 